\title{
Pääkirjoitus
}

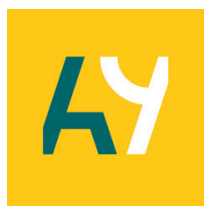

Ari Jokinen ${ }^{a}$, Anna Heikkinen ${ }^{b}$

\section{Luontopohjaiset ratkaisut: käsitteen vakiintumisen reittejä}

Kaupungistuminen ja ilmastonmuutos ovat antaneet nostetta luontopohjaisten ratkaisujen yleistymiselle 2000-luvun lopulta alkaen. Etenkin Euroopan unioni on panostanut tämän uuden käsitteen tutuksi tekemiseen ja käytännön kehitystyöhön. Luontopohjaiset ratkaisut (nature-based solutions) ovat luontoon tukeutuvia toimintatapoja selvästi rajattujen yhteiskunnallisten ongelmien ratkaisemiseksi. Niiden tavoitteena on tuottaa samanaikaisesti ihmisille ja luonnolle pitkäkestoisia kestävyyshyötyjä käyttäen systeemistä lähestymistapaa. Suomessa luontopohjaisia ratkaisuja hyödynnetään esimerkiksi kaupunkien lisääntyvien hulevesien hallinnassa. Tällöin sade- ja sulamisvedet ohjataan viemäreiden sijaan erilaisiin puroihin ja kosteikkoihin, joissa kasvit ja ekologiset prosessit viivyttävät ja puhdistavat vettä. Näin voidaan usein vähentää tulvariskejä, suojella alapuolisia vesistöjä ja edistää virkistyskäyttöä ja luonnon monimuotoisuutta. Luontopohjaisten ratkaisujen perusidea on helposti ymmärrettävä ja puhuttelee päätöksentekijöitä, kansalaisryhmiä, yrityksiä ja eri alojen tutkimusta.

Tämä teemanumero keskittyy luontopohjaisiin ratkaisuihin ja esittelee niiden suomalaista, monitieteistä tutkimusta ja tutkimusideoita. Haimme teemanumeroon kirjoituksia, jotka hahmottavat luontopohjaisten ratkaisujen käsitteellistä kehittymistä ja vaikutuksia. Tavoitteena oli myös tarkastella luontopohjaisia ratkaisuja nykyisen hallinnollis-tieteellisen keskustelun ulkopuolella, nostaa esiin kehittyviä toimintatapoja ja eri sidosryhmien osallistumista ratkaisujen kehittämiseen. Teemanumeroon sisältyvät kirjoitukset tarjoavatkin kuvauksen käsitteen kehittymisestä sekä siitä, millaisia reaktioita, kokeiluja, sovelluksia ja strategioita käsite on saanut aikaan Suomessa.

Yksittäisellä käsitteellä voi olla huomattava vaikutus ympäristöpolitiikan kehitykseen. Sen jälkeen kun "ympäristö" ja "kestävä kehitys" vakiintuivat poliittiseen puheeseen, uusia ympäristöhallinnan käsitteitä on ilmaantunut toistuvasti. Osa niistä osoittautuu elinkelpoisiksi. Ympäristöpolitiikan tutkijat James Meadowcroft ja Daniel J. Fiorino (2017) esittävät toimittamansa teoksen Conceptual innovation in environmental policy yhteenvedossa päätelmiä käsitteiden synnystä, vakiintumisesta, elinkaaresta ja poliittisesta vaikuttavuudesta. Heidän mukaansa uusi ympäristöpolitiikan käsite voi tulla elinvoimaiseksi, jos se perustuu käsitteen onnistuneeseen esille tuontiin ja selvään ideaan, jolla on poliittista vetovoimaa. Ennen kaikkea sen on tarjottava uusi ratkaisu havaittuun ongelmaan, jota aikaisemmat keinot eivät ole kyenneet selvittämään. Käsitteen on onnistuttava muotoilemaan ympäristöongelma ymmärrettäväksi ja mahdolliseksi ratkaista. Sen lisäksi käsitteelle on eduksi, jos se vetoaa eri toimialoihin, sillä on tunnistettavia

a Johtamisen ja talouden tiedekunta, Tampereen yliopisto, ari.k.jokinen@tuni.fi

bohtamisen ja talouden tiedekunta, Tampereen yliopisto 
yhteyksiä aikaisempaan käsitteistöön ja arkikieleen ja se löytää paikkansa institutionaalisissa käytännöissä, rakenteissa ja poliittisessa diskurssissa.

Luontopohjaisten ratkaisujen käsite vaikuttaa helposti omaksuttavalta ja merkitykselliseltä siksi, että se on hengeltään sekä vanha että uusi. Kaupunkipuistoliike PohjoisAmerikassa ja siirtolapuutarhat Euroopassa saivat jalansijaa jo 1800-luvulla reaktiona teollistumisen aiheuttamiin haittoihin kaupungeissa, ja ajatus puutarhakaupungista sai tulta alleen 1900-luvun alun Englannissa. Nämä kaupunkiluonnon merkitystä korostavat virtaukset vaikuttivat selvästi suomalaisten kaupunkien kehitykseen. Merkittävä muutos kaupunkiluonnon ymmärryksessä tapahtui globaalin ympäristöhuolen herättämänä viime vuosisadan loppupuoliskolla. Kaupunkiluonnon vaaliminen viheralueina edistyi tuona aikana merkittävästi. Rinnalla kehittyi ajatus siitä, että kaupungit voivat ratkaista globaaliongelmia paikallisesti - myös viheralueidensa välityksellä - ja vaikuttaa suotuisasti kestävyyden kokonaiskehitykseen (Duvall ym. 2018). Tämä perustui ajatukseen, että kaupungit ovat sosioekologisia järjestelmiä. Kaupunkiluonnon ymmärtäminen osaksi tätä kehitystä helpottui, kun avuksi tuli kokonainen uusien ympäristökäsitteiden perhe. Luonnon monimuotoisuus, ekosysteemipalvelut, ekosysteemeihin perustuvat muut hallinnan käsitteet ja viherrakenne tulivat vuorollaan jäsentämään uudenlaista ajatusta kaupunkiluonnosta. Niiden vaikutus säilyy edelleen. Viimeisenä käsitteenä mukaan on tullut luontopohjaiset ratkaisut. Monet pitävät sitä edellisten kattokäsitteenä, koska se on laaja-alainen ja vie kestävyystavoitteita kohti konkreettista ongelmanratkaisua.

Mielikuva uudesta ja samaan aikaan vanhasta käsitteestä syntyy myös siksi, että luontopohjaisten ratkaisujen tutkimus on alkanut jo ennen kuin käsite edes syntyi. Kaupunkiluonnon terveys- ja hyvinvointivaikutusten tutkimus (esim. Korpela ym. 2008) on esimerkki tällaisesta jo aikaisemmin aloitetusta pioneerityöstä, kun taas viherkattojen tutkimus pääsi vauhtiin vasta myöhemmin ja kotoutui suoraan luontopohjaisten ratkaisujen aikakaudelle. Ajallisia siirtymiä tulee näkyviin myös tarkastelemalla millaisia luontopohjaisia ratkaisuja ihmiset ovat kautta aikain keksineet esimerkiksi puutarhanhoidossa, metsästyksessä, kaupunkiasumisessa, maanviljelyssä tai metsätaloudessa. Niitä koskeva paikallinen tietämys voi olla arvokas voimavara luontopohjaisten ratkaisujen suunnittelijoille ja tutkijoille.

Parhaillaan luontopohjaisten ratkaisujen käsite elää kukoistavaa nuoruusvaihettaan. Ratkaisuja ideoidaan, kokeillaan ja tutkitaan laajalla rintamalla niin Suomessa kuin kansainvälisesti. Käsitteen ilmaantuminen politiikkaan ja käytännön ongelmanratkaisuun kaupungeissa ja muualla on kiinnostava ilmiö juuri tässä vaiheessa. Nuoruusvaiheessa tapahtuu samaan aikaan sekä institutionaalista vakiintumista että syveneviä ja myös kokonaan uusia tapoja tulkita, mikä on luontopohjainen ratkaisu, millaista on sen tarkoittama luonto, mitä lisäarvoa käsite tuo eri yhteyksissä ja eri toimijoille, ja mitä uusia yhteiskunnan ongelmien määrittelyitä ja ratkaisumahdollisuuksia se nostaa esiin.

Luontopohjaisten ratkaisujen käsitteestä ei ole täydellistä yhteisymmärrystä, sillä sen määrittely on vielä kesken. Monet tutkijat pitävät tärkeänä määritellä nykyistä tarkemmin, millaiset tapaukset ovat tai eivät ole luontopohjaisia ratkaisuja. Toisaalta käsitteen avoin luonne ja tulkinnanvaraisuus voivat edistää sen menestymistä, sillä ne takaavat, että eri osapuolet pystyvät tulemaan mukaan yhteistyöhön ja havaitsemaan sen itselleen hyödylliseksi. Joustavuus ja väljyys voivat edistää myös ideatuotantoa ja vanhojen kestämättömien ratkaisujen korvaamista luonnonmukaisemmilla. Käsitteen nuoruusvaihe, jossa luontopohjaiset ratkaisut nyt ovat, on hedelmällisin uusille ideoille, mikä on tullut esiin myös ekoinnovaatioiden tutkimuksessa. Innovaation elinkaaren hedelmällinen vaihe alkaa jo idean kehittelystä ja alkuvaiheen luonnostelusta, jolloin vallitsee näkökulmien runsaus, ja hiipuu oppimiskäyrän saavuttaessa käännepisteensä. Luontopohjaisten ratkaisujen nuoruusvaihe on suotuisa myös sellaiselle tutkimukselle, joka pyrkii luotaamaan ihmistoimintojen ja luonnon välisïa suhteita kokonaan uusista näkökulmista.

Meneillään olevaan kehitysvaiheeseen sisältyy muun muassa seuraavia kysymyksiä: 
Keiden luonnosta on kyse, ja keille luontopohjaisia ratkaisuja luodaan? Ketkä ovat olennaisia yhteistyön osapuolia eri tapauksissa silloin, kun kaupunkiluonnolla pyritään tuottamaan paikallisia ratkaisuja globaaliongelmien aiheuttamiin muutoksiin? Voidaanko luontopohjaisia ratkaisuja kehittää nykyistä painokkaammin luonnon näkökulmasta? Luontopohjaisten ratkaisujen yhteydessä EU korostaa innovaatioita, markkinoita ja talouskasvua, mikä voi johtaa liian kapeaan ajatteluun. Sen sijaan edistyksellinen ekologinen innovatiivisuus edellyttäisi sitä, että luonto ei ole ensisijaisesti talouskasvun resurssi vaan enemmänkin tiedon lähde taloudelliselle ja muulle toiminnalle, jonka avulla luonnon ekologista elinvoimaisuutta voidaan vahvistaa (Hofstra \& Huisingh 2014).

Teemanumeron avaavat Suvi Vikström ja kumppanit esittelemällä toimintakentän, jossa luontopohjaisia ratkaisuja tällä hetkellä suunnitellaan ja toteutetaan Suomessa ja kansainvälisesti. Kirjoitus kattaa käsitteen tärkeimpiä tämän hetken ulottuvuuksia, esittelee hallintamalleja ja käsitteen pääasiallisen kehittämispolun kohti vakiintuvaa täytäntöönpanoa. Artikkelissa keskitytään monihyötyisyyden tavoitteeseen ja esitellään myös TASAPELIhankkeessa tunnistettuja luontopohjaisten ratkaisujen edistämisen keinoja Suomessa.

Teemanumeron yhtenä näkökulmana käsitellään luontopohjaisten ratkaisujen syventymistä ja paikallista juurtumista. Paikallista sovittamista tarvitaan, sillä ympäristötekijät, toimijaverkostojen yhteistyökyky ja poliittinen kulttuuri vaihtelevat alueellisesti ja ajallisesti. Maarit Särkilahti, Kaisa Mustajärvi ja Salla Leppänen käsittelevät artikkelissaan luontopohjaisten ratkaisujen yhteiskehittämistä kaupunkiympäristöissä ja siihen liittyen yhdessä oppimista. Nämä toimintatavat edistävät kaupunkilaisten osallistumista. Vuorovaikutus eri toimijoiden välillä on välttämätöntä myös siksi, että luontopohjaisten ratkaisujen toteuttamisessa on ylitettävä vakiintuneiden instituutioiden muodostamia esteitä eli polkuriippuvuuksia. Luontopohjaisten ratkaisujen suunnittelussa tarvitaan usein pitkälle menevää tekniikan ja luonnon tietämystä. Harry Edelman ja kollegat esittävät tästä kokeelliseen testaamiseen perustuvan esimerkin, joka käsittelee kaupunkivihreän ja rakennettujen pintojen yhdistämistä. Artikkeli tuottaa uutta tutkimustietoa siitä, kuinka viherseinät voivat suojella rakennuksia Suomen ilmasto-oloissa sen lisäksi että ne tuottavat luontoon yhdistettäviä muita hyötyjä.

Tyypillisten luontopohjaisten ratkaisujen rinnalle on nousemassa uusia, tutkiskelevia lähestymistapoja. Asta Salmi, Elina Karttunen ja Anne Quarshie tarkastelevat artikkelissaan yritysten mahdollisuuksia edistää luonnon monimuotoisuuden suojelua toimitusketjujen hallinnan avulla, kenties luontopohjaisia ratkaisuja apuna käyttäen. Keskustelunavaus on tärkeä siksi, että yrityksiä ja uusia liiketoimintamalleja tarvitaan kestävyyssiirtymien mahdollistamiseksi, ja myös siksi että toimitusketjut voivat tarjota konkreettisen mahdollisuuden hidastaa kaupunkien aiheuttamaa rasitusta luonnon monimuotoisuudelle jopa maapallon toisella puolen olevissa kohteissa. Jani Pulkin, Jutta Pulkin ja Tere Vadénin artikkelissa tuodaan mukaan ekoterveyskasvatus uutena luontopohjaisten ratkaisujen näkökulmana ja jäsennetään sen teoreettista perustaa. Ekoterveyskasvatus tunnustaa luonnon keskeisen merkityksen ihmisten terveydelle sekä tarpeen luoda nykyistä syvempiä vastavuoroisia, käytännöllisiä ja vastuullisia suhteita ihmisten ja luonnon välille. Samalla on purettava vanhoja, lukkiutuneita ajattelutapoja.

Luontopohjaisten ratkaisujen kehityksessä tapahtuu myös aiemmin virinneiden tutkimusnäkökulmien uudelleen kohdentumista tai laajentumista. Seuraavat kaksi katsausta liittyvät läheisesti luonnon terveyshyötyihin ja yhdyskuntasuunnitteluun. Riikka Puhakka ynnä muut esittelevät katsauksessaan tutkimushankkeen, joka suomalaisen tutkimuksen kautta tunnetuksi tulleen biodiversiteettihypoteesin pohjalta paneutuu päiväkotien pihoihin uutena mahdollisuutena lisätä kaupunkiympäristöjen terveysvaikutuksia. Ihmisten välittömät yhteydet luontoon, suoranaiset ihokontaktit sekä lasten tapa syödä savea, kariketta ja luteita ovat jääneet vähiin viime vuosikymmeninä, vaikka juuri niitä tarvittaisiin luontaisen vastustuskyvyn vahvistamiseen. Kaupunkilaisten liikkumisvaje on toinen 
ongelma, ja siihen paneutuvat katsauksessaan Jari Lyytimäki ja kumppanit. He yhdistävät liikenteen ja lihasvoimaisen liikkumisen ja hahmottelevat siltä pohjalta uutta lähestymistapaa luontopohjaisiin ratkaisuihin.

Teemanumeron kirjoitukset havainnollistavat, että luontopohjaisten ratkaisujen soveltaminen on Suomessa aktiivisessa vaiheessa ja soveltamisalue on laaja. Kirjoitukset myös osoittavat, että vakiintuminen ei tarkoita vain valtavirtaistumista yhdelle kapealle uralle. Rinnalla säilyy monenlaisia tulkintoja ja vaihtoehtoisia näkökulmia, jotka voivat käynnistää merkittäviä kehityssuuntia.

Kiitämme teemanumeron toteutumisesta Alue ja Ympäristö -lehteä ja Suomen Akatemiaa (nro 298663).

\section{Lähteet}

Duvall, P., Lennon, M. \& Scott, M. (2018) The ‘natures' of planning: Evolving conceptualizations of nature as expressed in urban planning theory and practice. European Planning Studies 26(3) 480-501. https://doi. org/10.1080/09654313.2017.1404556

Hofstra, N. \& Huisingh, D. (2014) Eco-innovations characterized: a taxonomic classification of relationships between humans and nature. Journal of Cleaner Production 66 459-468. https://doi.org/10.1016/j. jclepro.2013.11.036

Korpela, K. M., Ylén, M., Tyrväinen, L. \& Silvennoinen, H. (2008) Determinants of restorative experiences in everyday favorite places. Health \& Place 14(4) 636-652. https://doi.org/10.1016/j.healthplace.2007.10.008

Meadowcroft, J. \& Fiorino, D. J. (2017) Conceptual innovation and the future of environmental policy. Teoksessa Meadowcroft, J. \& Fiorino, D. J. (toim.) Conceptual innovation in environmental policy, 335-357. MIT Press, London. 